\title{
Penerapan Guided Inquiry Berbantu Memory Match Game untuk Meningkatkan Retensi dan Kemampuan Berpikir Kritis Siswa Kelas X SMA
}

\section{Implementing Guided Inquiry with Memory Match Game to Improve Students' Retention and Critical Thinking Skill}

\author{
KUMAYA AGUSTINA ${ }^{\mathbf{*}}$, METI INDROWATI ${ }^{1}$, RIEZKY MAYA PROBOSARI ${ }^{\mathbf{1}}$ \\ ${ }^{1}$ Pendidikan Biologi, Fakultas Keguruan dan Ilmu Pendidikan, Universitas Sebelas Maret. Jl. Ir. Sutami No.36A, Jebres, Kota Surakarta, \\ Jawa Tengah 57126, Indonesia \\ *Corresponding authors: kumaya_agustina@yahoo.com \\ Manuscript received: \\ Revision accepted:
}

\begin{abstract}
This research aimed to improve the retention and the critical thinking skill of the biology students in X grade of SMA N 1 Karanganyar through the implementation of Guided Inquiry assisted Memory Match Game. This research was a classroom action research which is divided by several cycles. Each cycle includes four stages: planning, action, observation, and reflection. The subject of this research is the students of X IPA 6 class of SMA N 1 Karanganyar in academic year of 2013/2014. Data collecting are test and non-test technique. The test is used in order to measure the retention and the critical thinking skill. Non-test of this research was observation, interview and documentation. Data analysis of this research was descriptive qualitative analysis and data validation by using triangulation method. The results of this research show that students retention and critical thinking skill increase. It can be seen in students retention from Pre-cycle, Cycle I, and Cycle II, it increase from $62,38 \%$ to $93,33 \%$. The critical thinking skill consist of 6 aspects includes; interpretation, analysis, evaluation, inference, explanation, and self regulation. Interpretation aspect increase from $64,76 \%$ to $53,33 \%$, analysis aspect increase from $52,14 \%$ to $82,85 \%$, evaluation aspect increase from $56,42 \%$ to $77,14 \%$, inference aspect increase from $53,57 \%$ to $88,57 \%$, explanation aspect increase from $54,28 \%$ to $76,42 \%$, and self regulation aspect increase from $56,71 \%$ to $85,71 \%$. Based on the results of this research, the researcher draws a conclusion that the implementation of Guided Inquiry with Memory Match Game can improve students retention and the critical thinking,
\end{abstract}

Keywords: Guided Inquiry, Memory Match Game, Retention, Critical Thinking Skill

\section{PENDAHULUAN}

Hasil observasi awal tanggal 10 September sampai dengan 7 Desember tahun 2013 disalah satu SMA negeri di Karanganyar menunjukkan bahwa siswa kurang mengkritisi soal-soal yang diberikan guru. Hal ini dibuktikan dengan kurangnya siswa dalam melakukan interpretasi (interpretation), analisis (analysis), evaluasi (evaluation), penjelasan (explanation), menyimpulkan (inferensi) dan pengaturan diri (self regulation) terhadap soal-soal yang diberikan guru.

Observasi kedua dilakukan untuk mengetahui melalui pengamatan langsung, wawancara dengan guru dan siswa pada tanggal 14 Januari sampai dengan 30 Januari tahun 2014. Berdasarkan hasil pengamatan setelah siswa diberi soal terlihat bahwa siswa kurang memiliki kemampuan berpikir kritis terhadap masalah-masalah yang diberikan oleh guru, yang meliputi aspek melakukan interpretasi (interpretation), analisis (analysis), evaluasi (evaluation), penjelasan (explanation), menyimpulkan (inferensi) dan pengaturan diri (self regulation). Kemampuan interpretasi masih kurang dibuktikan dengan siswa kurang bisa menyatakan arti suatu informasi dari soal yaitu hanya sebesar 64,76\%. Kemampuan analisis masih kurang dibuktikan hanya sedikit siswa yang menjawab benar dalam menganalisa soal yaitu hanya sebesar $52,14 \%$. Kemampuan evaluasi masih kurang dibuktikan pemberian soal yang bersifat menilai suatu pernyataan, siswa masih belum benar dalam menjawab dengan persentase sebesar $56,42 \%$. Kemampuan penjelasan sudah baik, tetapi siswa dalam menjawab soal ini masih tidak berdasarkan bukti atau konsep yaitu sebesar 54,28\%. Kemampuan menyimpulkan masih kurang karena siswa kurang bisa menyimpulkan berdasarkan alasan yaitu hanya sebesar $53,57 \%$. Kemampuan pengaturan diri siswa masih kurang karena soal yang disajikan adalah bersifat mengevaluasi konsep, siswa masih salah dalam menjawab sebesar $65,71 \%$.

Hasil wawancara dengan siswa menunjukkan bahwa siswa banyak mengeluh karena pembelajaran biologi dianggap sulit, hal ini karena banyaknya nama ilmiah atau latin yang harus dihafalkan sehingga siswa merasa kesulitan untuk menghafalkan. Menghafal erat hubungannya dengan proses mengingat yaitu proses untuk menerima, menyimpan dan memproduksi tanggapantanggapan yang telah diperoleh individu (Suryabrata, 1989). Salah satu fungsi dari mengingat adalah memproduksi kesan-kesan, di dalam fungsi tersebut terdapat dalam dua bentuk yaitu mengenali dan mengingat kembali. Bentuk tersebut merupakan aspek dari retensi. Retensi merupakan tingkatan terendah dalam dimensi proses kognitif, karena didalam retensi hanya terdapat proses mengingat yaitu hanya menumbuhkan kemampuan 
untuk meretensi materi pelajaran sama seperti materi yang diajarkan (Anderson \& Krathwohl, 2010). Hal ini menunjukkan bahwa siswa kurang memiliki retensi terhadap pembelajaran biologi khususnya nama ilmiah.

Hasil observasi menunjukkan bahwa proses pembelajaran di kelas X IPA 6 kurang mengembangkan retensi dan kemampuan berpikir kritis. Sawrey dan Telford (1968) menyatakan bahwa retensi merupakan pengalaman yang tersimpan selama proses belajar. Retensi adalah kegiatan belajar yang berhubungan antara kemampuan dengan ketrampilan daya ingat siswa (Purnamawati, 2011). Retensi juga memiliki hubungan erat dengan memori jangka pendek (short term memory) dan memori jangka panjang (long term memory). Peningkatan retensi dapat dibantu dengan menggunakan media pembelajaran yaitu melalui pembelajaran berbasis teknologi multimedia interaktif (Tapilouw \& Setiawan, 2008). Salah satunya yaitu dengan game, game yang digunakan adalah adalah memory match game. Memory match game adalah sebuah permainan yang didalamnya terdapat tes dan melatih kemampuan untuk mengidentifikasi, mengenali dan ingat gambar dalam urutan tertentu. Pemain disajikan dengan berbagai jenis gambar dalam kelompok-kelompok kecil. Pemain perlu mengingat gambar dalam urutan yang disajikan sehingga urutan yang benar dapat diidentifikasi. Program ini melatih keterampilan antara lain pengenalan gambar, perhatian pendengaran, perhatian visual, dan mempertajam memori dan kecepatan pemrosesan.

Berpikir kritis adalah perwujudan perilaku belajar yang berkaitan dengan pemecahan masalah (Sumaryati \& Sumarmo, 2013). Berpikir kritis berarti berhati-hati dalam proses berpikir, hal ini untuk memperjelas dalam pemahaman dan membuat keputusan yang baik (Chaffe, 2010). Elder \& Paul (2007) mengemukakan kemampuan berpikir kritis akan dimiliki siswa jika membangun konsepnya sendiri, dengan memecahkan masalah, memberikan alasan atau pernyataan terhadap sesuatu yang diyakini, yang didukung oleh tahap analisis, pengujian dan evaluasi. Salah satu proses pembelajaran yang banyak melibatkan kegiatan analisis, pengujian dan evaluasi adalah Guided Inquiry (Bell, Smetana \& Binns, 2005). Johnson (2002) berpendapat bahwa berpikir kritis merupakan sebuah proses yang terarah dan jelas yang dapat digunakan untuk kegiatan memecahkan masalah, mengambil keputusan, menganalisis asumsi, melakukan penelitian ilmiah, berpendapat dengan cara yang terorganisasi serta mengevaluasi pendapat. Langkah-langkah pembelajaran Guided Inquiry terdiri dari 4 fase yaitu memberikan wilayah percobaan dengan menyajikan permasalahan, menyusun permasalahan dengan merumuskan masalah dan membuat hipotesis, mengidentifikasi permasalahan melalui percobaan dengan merancang percobaan dan melakukan percobaan, menentukan cara untuk menyelesaikan permasalahan dengan mengumpulkan, menganalisis data serta membuat kesimpulan (Joyce \& Weil, 2000).

\section{METODE PENELITIAN}

Penelitian adalah Penelitian Tindakan Kelas (PTK) yang bertujuan untuk mengetahui penerapan guided inquiry berbantu memory match game untuk meningkatkan retensi Biologi siswa sma dan mengetahui penerapan guided inquiry berbantu memory match game untuk meningkatkan kemampuan berpikir kritis Biologi siswa SMA.

Prosedur penelitian mengikuti model yang dikembangkan oleh Kemmis dan Robin MC Taggart dalam Arikunto (2008) yang berupa model spiral yaitu dalam satu siklus terdiri dari tahap perencanaan, tindakan, observasi dan refleksi. Pelaksanaan tindakan siklus dilaksanakan setelah observasi pra-siklus.

Penerapan tindakan berupa Guided Inquiry berbantu Memory Match Game dilaksanakan dalam dua siklus yaitu siklus I dan siklus II. Siklus I direncanakan dan dilaksanakan berdasarkan hasil analisis observasi prasiklus, siklus II direncanakan dan dilaksanakan berdasarkan refleksi siklus I, sehingga penerapan Guided Inquiry berbantu Memory Match Game meningkatkan retensi dan kemampuan berpikir kritis.

\section{HASIL DAN PEMBAHASAN}

Hasil penelitian menunjukkan perbandingan rata-rata retensi siswa tingkat pada prasiklus, siklus I, dan siklus II disajikan dalam Gambar 1.

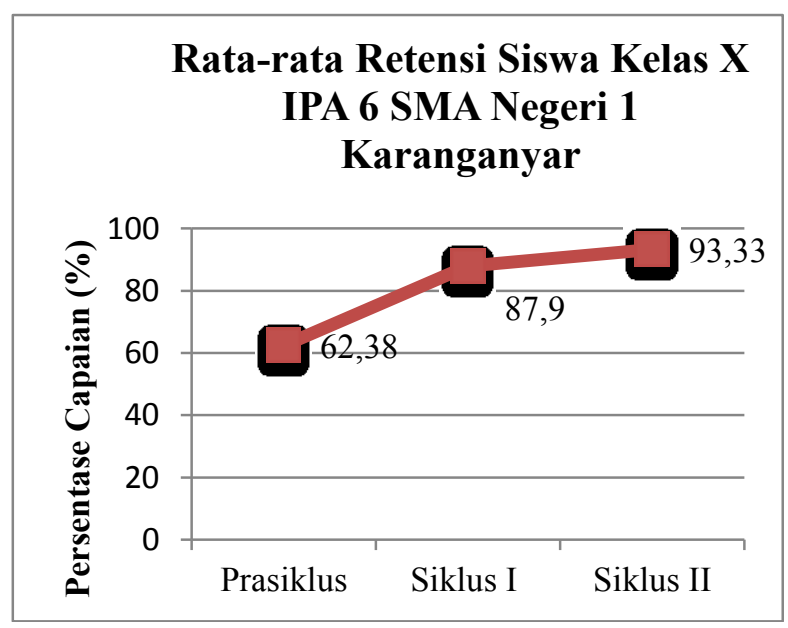

Gambar 1. Perbandingan hasil capaian rata-rata retensi siswa pada Pra Siklus, Siklus I, dan Siklus II

Hasil capaian kemampuan berpikir kritis rata-rata siswa pada pra siklus, siklus I, dan siklus II pada Gambar 2. 


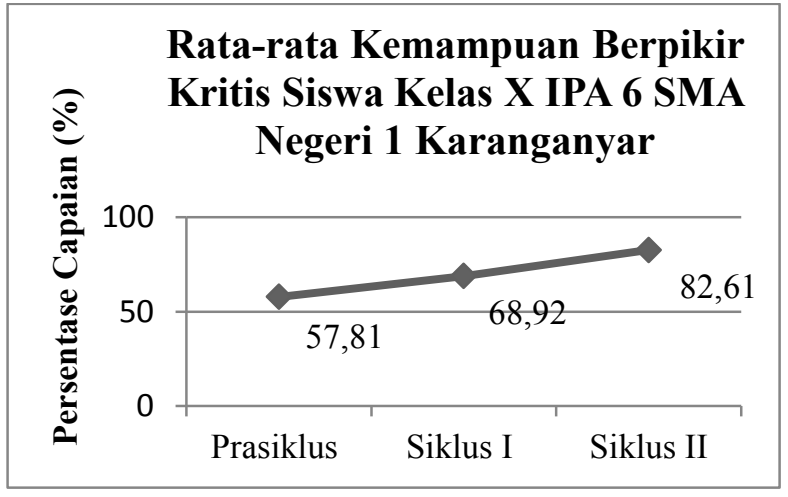

Gambar 2. Perbandingan hasil capaian kemampuan berpikir kritis rata-rata siswa pada pra siklus, siklus I, dan siklus II

Gambar 1 menunjukkan bahwa skor retensi siswa mengalami peningkatan dari prasiklus hingga siklus II. Perbandingan tingkat skor postest dan retest siswa pada prasiklus, siklus I, dan siklus II disajikan dalam Tabel 1.

Tabel 1. Skor Capaian postest dan retest siswa pada prasiklus, siklus I, dan siklus II

\begin{tabular}{ccccc}
\hline \multirow{2}{*}{ No } & \multirow{2}{*}{ Ket } & \multicolumn{3}{c}{ Capaian Presentase (\%) } \\
\cline { 3 - 5 } & & Pra-siklus & Siklus I & Siklus II \\
\hline $\mathbf{1}$ & Postest & 62,38 & 91,93 & 85,71 \\
$\mathbf{2}$ & Pretest & & 83,74 & 80 \\
\hline
\end{tabular}

Gambar 2 menunjukkan bahwa rata-rata kemampuan berpikir kritis siswa mengalami peningkatan dari prasiklus hingga siklus II. Perbandingan rata-rata capaian tiap aspek kemampuan berpikir kritis siswa pada prasiklus, siklus I, dan siklus II disajikan dalam Tabel 2.

Tabel 2. Perbandingan Rata-Rata Capaian Tiap Aspek Kemampuan Berpikir Kritis Siswa pada Prasiklus, Siklus I, dan Siklus II

\begin{tabular}{ccccc}
\hline \multirow{2}{*}{ No } & Aspek & \multicolumn{3}{c}{ Capaian Presentase (\%) } \\
\cline { 3 - 5 } & & $\begin{array}{c}\text { Pra } \\
\text { siklus }\end{array}$ & Siklus I & Siklus II \\
\hline 1 & Menginterpretasi & 64,76 & 74,28 & 85 \\
2 & Menganalisis & 52,14 & 60 & 82,85 \\
3 & Mengevaluasi & 56,42 & 60,71 & 77,14 \\
4 & Menyimpulkan & 53,57 & 74,28 & 88,57 \\
5 & Menjelaskan & 54,28 & 77,14 & 76,42 \\
6 & Pengaturan diri & 65,71 & 67,14 & 85,71 \\
\hline
\end{tabular}

Penerapan model pembelajaran Guided Inquiry berbantu Memory Match Game dilaksanakan selama dua siklus. Siklus I menggunakan sub materi Echinodermata, Siklus II menggunakan sub materi Mollusca. Model pembelajran Guided Inquiry berbantu Memory Match Game terdiri dari 4 fase yaitu Memberikan wilayah percobaan dengan menyajikan permasalahan, menyusun permasalahan dengan merumuskan masalah dan membuat hipotesis, mengidentifikasi permasalahan melalui percobaan dengan merancang percobaan dan melakukan percobaan, menentukan cara untuk menyelesaikan permasalahan dengan mengumpulkan, menganalisis data serta membuat kesimpulan (Joyce \& Weil, 2000).
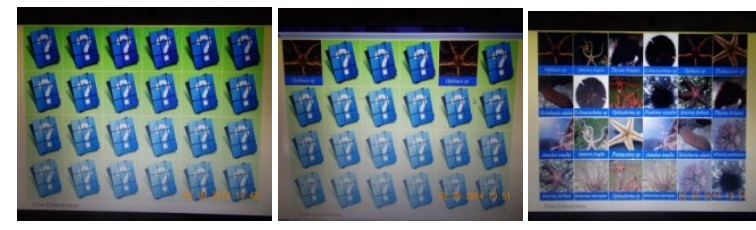

Gambar 3. Tampilan Memory Match Game Siklus I

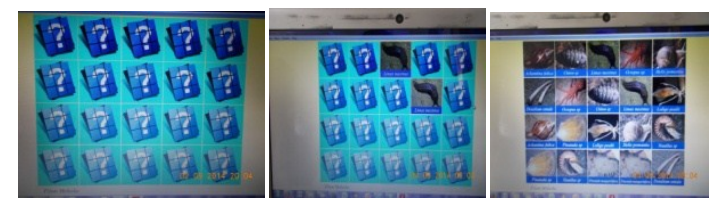

Gambar 4. Tampilan Memory Match Game Siklus II

Fase memberikan wilayah percobaan dengan menyajikan permasalahan, pada kegiatan ini guru memberikan suatu fenomena. Pada siklus I dengan menunjukkan video untuk menemukan ciri-ciri, klasifikasi dan contoh berbagai macam hewan yang masuk ke dalam filum Echinodermata. Sedangkan kegiatan siswa adalah mengamati fenomena masalah yang disajikan oleh guru. Pada kegiatan ini tidak semua siswa memperhatikan, beberapa siswa tidak memperhatikan fenomena yang disajikan oleh guru karena pembelajaran biologi berada di jam terakhir sehingga beberapa siswa mengantuk. Sedangkan pada siklus II dengan menunjukkan video filum Mollusca, siswa mengamati fenomena masalah yang disajikan oleh guru. Pada kegiatan ini tidak semua siswa memperhatikan, ada siswa yang tidak memperhatikan fenomena yang disajikan oleh guru. Tetapi jika dibandingkan siklus I pada siklus II siswa yang tidak memperhatikan lebih sedikit.

Fase menyusun permasalahan dengan merumuskan masalah dan membuat hipotesis. Pada siklus I guru membimbing siswa untuk mendiskusikan judul, rumusan masalah dalam bentuk pertanyaan, tujuan percobaan berdasarkan pengamatan terhadap permasalahan yang terkait dengan tujuan pembelajaran yaitu ciri-ciri, klasifikasi dan contoh berbagai macam hewan yang masuk ke dalam filum Echinodermata. Pada tahapan ini kegiatan siswa adalah secara berkelompok mendiskusikan judul, rumusan masalah dalam bentuk pertanyaan seperti bagaimana ciri-ciri filum Echinodermata, bagaimana klasifikasi dari Filum Echinodermata dan apa contoh spesies dari filum Echinodermata, tujuan percobaan berdasarkan pengamatan terhadap permasalahan. Pada tahap ini beberapa siswa belum paham tentang intruksi dari guru, sehingga guru harus mengulangi intruksi kembali. 
Pada siklus II dengan tahapan yang sama akan tetapi dengan sub materi Mollusca. Siswa sudah mulai paham tentang intruksi dari guru, berdasarkan pengalaman di pembelajaran sebelumnya yaitu pada siklus I. Siswa terlihat sudah terbiasa dalam menyusun permasalahan sehingga hampir semua siswa aktif dalam mengungkapkan pendapat, ide, dan tanggapan terhadap fenomena yang disajikan guru. Aspek kemampuan berpikir kritis yang ditingkatkan pada sintaks menyusun permasalahan adalah menganalisis. Hal ini sejalan dengan Chin (2013) yang menyatakan bahwa penyajian masalah nyata yang tidak terstruktur membutuhkan pemikiran yang mendalam, sehingga mampu mengakomodasi kemampuan menganalisis.

Kegiatan menyusun hipotesis, pada tahapan ini guru membimbing siswa untuk membuat hipotesis berdasarkan rumusan masalah yang dibuat yaitu bagaimana ciri-ciri filum Echinodermata, bagaimana klasifikasi dari Filum Echinodermata dan apa contoh spesies dari filum Echinodermata. Siswa secara berkelompok membuat hipotesis berdasarkan rumusan masalah yag dibuat. Siswa merasa kebingungan untuk membuat hipotesis, sehingga guru menjelaskan kembali tentang maksud dari hipotesis. Setelah dijelaskan berulang-ulang sehingga siswa paham maksud dari membuat hipotesis. Pada siklus II siswa sudah paham untuk membuat hipotesis, hal ini dikarenakan pada siklus I siswa sudah dijelaskan bagaimana membuat hipotesis. Menurut Facione (2011) kemampuan untuk mengidentifikasi dan memilih unsur-unsur yang diperlukan untuk membentuk kesimpulan yang beralasan dapat dibentuk melalui hipotesis dengan memperhatikan informasi yang relevan.

Fase mengidentifikasi permasalahan melalui percobaan dengan merancang percobaan dan melakukan percobaan. Kegiatan merancang percobaan, pada kegiatan ini guru membimbing siswa untuk merancang percobaan meliputi menentukan alat, bahan dan langkah kerja sebagai usaha untuk mencari jawaban atas pertanyaan yang telah dibuat. Guru juga membimbing siswa untuk mengambil alat-alat dengan melakukan bon alat yang diperlukan untuk melakukan percobaan. Guru membimbing siswa melakukan pengamatan terhadap filum Echinodermata sesuai dengan rancangan percobaan yang telah disusun pada setiap kelompok. Pada sintak ini siswa menulis rancangan percobaan pada LKS, perwakilan dari kelompok maju ke depan dengan membawa bon alat untuk mengambil alat-alat yang diperlukan untuk pengamatan. Kemudian siswa mengamati awetan Echinodermata. Pada saat pengamatan sebagian siswa merasa keberatan untuk melakukan pengamatan dikarenakan awetan yang diamati berbau menyengat yang tidak sedap. Pada siklus II saat pengamatan sebagian siswa sudah merasa tidak keberatan untuk melakukan pengamatan dikarenakan awetan yang diamati merupakan hewan basah yang belum diawetkan menggunakan formalin seperti pada pengamatan siklus I.

Kegiatan melakukan percobaan, Kegiatan pada tahap ini guru membimbing siswa untuk mengeksplorasi sebanyak-banyaknya sumber data yaitu filum Echinodermata untuk mendapatkan informasi yang dibutuhkan atas usaha menjawab pertanyaan atau rumusan masalah yang telah disusun. Guru juga membimbing siswa untuk mencatat semua informasi yang telah diperoleh dari percobaan pada LKS. Kegiatan yang dilakukan siswa pada tahap ini adalah siswa mengeksplorasi sebanyakbanyaknya tentang filum Echinodermata melalui pengamatan awetan, literatur baik buku dan internet. Siswa juga menulisakan jawaban dari pertanyaan yang ada di LKS. Pada siklus II Siswa juga menulisakan jawaban dari pertanyaan yang ada di LKS.

Fase menentukan cara untuk menyelesaikan permasalahan dengan mengumpulkan, menganalisis data serta membuat kesimpulan. Pada kegiatan ini guru membimbing siswa untuk menjawab pertanyaan berdasarkan data yang diperoleh dari kegiatan percobaan dengan menuliskan jawaban pada LKS. Kegiatan siswa pada tahap ini secara berkelompok menuliskan jawaban pertanyaan pada LKS dengan menghubungkan pengalaman yang telah dimiliki dengan data dan informasi yang diperoleh pada kegiatan percobaan. Dalam kegiatan ini siswa bekerjasama dengan cukup baik. Pada siklus II siswa bekerjasama dengan cukup baik. Didalam proses mengumpulkan data terdapat aktivitas menjaring informasi yang dibutuhkan untuk menguji hipotesis yang diajukan (Budiartini, 2013). Pada tahap pengumpulan data kemampuan berpikir kritis siswa akan lebih berkembang melalui pencarian sumber atau informasi yang relevan dengan rumusan masalah dan hipotesis yang dibuat. Proses pencarian informasi atau sumber yang relevan merupakan proses investigasi secara teoritik dari kemampuan berpikir kritis yaitu menginterpretasi (Sutama, 2014).

Untuk membantu menguji ingatan siswa dan untuk membantu proses pembelajaran ditambahkan dengan game yaitu Memory Match Game, sebelum dilakukan game guru mendemonstrasikan cara melakukan permainan mengenai nama-nama ilmiah dari filum Echinodermata melalui Memory Match Game. Kemudian guru membimbing siswa untuk melakukan permainan mengenai nama-nama ilmiah dari filum Echinodermata melalui Memory Match Game dengan menunjukkan perwakilan kelompok. Memperhatikan demonstrasi dari guru cara melakukan permainan mengenai nama-nama ilmiah dari filum Echinodermata melalui Memory Match Game. Melakukan permainan mengenai nama-nama ilmiah dari filum Echinodermata melalui Memory Match Game dengan mengirimkan perwakilan kelompok. Sedangkan siswa yang tidak maju untuk tes Memory Match Game duduk dibelakang dengan memperhatikan siswa yang memainkan game kemudian sambil mengisi LKS yang jawabannya ada di dalam game. Beberapa siswa tidak memperhatikan. Pada siklus II masih ada siswa yang belum memperhatikan.

Kegiatan membuat kesimpulan, pada tahap ini kegiatan yang dilakukan adalah guru membimbing siswa untuk menyimpulkan hasil percobaan. Guru menunjuk dan membimbing siswa secara berkelompok untuk menyampaikan hasil percobaan dan diskusi. Guru memberikan kesempatan kepada siswa kelompok lain untuk bertanya kepada kelompok presentator dan menambahkan jika ada penjelasan yang belum disampaikan oleh kelompok presentator. Guru menunjuk 
siswa untuk menyimpulkan hasil diskusi dan percobaan pada kegiatan pembelajaran. Siswa pada tahap ini membuat kesimpulan dengan teman kelompok, setelah itu maju ke depan kelas untuk menyampaikan hasil diskusi tiap kelompok. Ketika presentasi, sebagian siswa tidak memperhatikan teman yang sedang presentasi. Kemudian waktu yang digunakan untuk presentasi terlalu menyita banyak waktu. Kemudian pada tahap ini siswa tidak ada yang ditunjuk untuk membuat hasil diskusi secara mandiri. Pada siklus II Siswa Ketika presentasi, masih ada sebagian siswa yang tidak memperhatikan teman yang sedang presentasi, ini menandakan bahwa jalannya presentasi kurang terorganisir dengan baik. Kemudian pada tahap ini siswa sudah ada yang ditunjuk untuk membuat hasil diskusi secara mandiri. Didalam kegiatan presentasi, terdapat proses menjelaskan yaitu kemampuan untuk menyatakan hasil atau alasan berdasarkan bukti dengan berupa argumentasi yang meyakinkan (Facione, 2011). Pada tahap penyimpulan, siswa akan melibatkan berbagai aspek dalam kemampuan berpikir kritis yaitu berpikir logis, proses induktif, deduktif, evaluatif, memberikan argumen yang logis dalam pengambilan keputusan (Sutama, 2014). Mengevaluasi dapat diakomodasikan dalam kegiatan menyimpulkan.

Setelah semua sintak kegiatan dilakukan guru mengkonfirmasi dan merefleksi tentang materi yang dipelajari hari ini tetapi pada saat mengkonfirmasi materi kurang ditekankan, selain itu guru juga belum memperdalam kesimpulan diskusi dari LKS saat penyampaian materi. Pada tahap ini terdapat proses pengaturan diri, yaitu dimana seseorang dapat menganalisis dan mengevaluasi kemampuan diri dalam mengambil kesimpulan dengan bentuk koreksi (Facione, 2011). Guru dan siswa juga akan melakukan refleksi terhadap proses kegiatan pembelajaran guna memperbaiki dan menyempurnakan kegiatan pembelajaran berikutnya.

Retensi mengalami peningkatan dari prasiklus hingga siklus II. Hasil tes retensi pada siklus I dilakukan dua kali yaitu postest dan retest. Hasil postest dan retest pada siklus I tidak mengalami perbedaan yang signifikan yaitu mengalami penurunan sebesar $8,19 \%$. Hal ini menunjukkan bahwa siswa memiliki retensi yang sudah cukup baik akan tetapi perlu ditingkatkan. Hasil tes pada siklus II postest dan retest menunjukkan bahwa terjadi penurunan yang tidak signifikan dari siklus I menuju siklus II yaitu sebesar $5,71 \%$. Tes retensi pada siklus II juga dilakukan dua kali yaitu postest dan retest. Hasil postest dan retest pada siklus II dimungkinkan siswa sudah mengenali tipe soal yang diberikan pada siklus I, sehingga pada siklus II retensi siswa sudah baik. Selain itu siswa juga sudah mengenali tipe game yang digunakan dalam pembelajaran. Retensi dalam hal ini ditekankan pada nama-nama ilmiah. Hasil wawancara siswa pada aspek retensi didapatkan bahwa siswa merasa senang, mudah mengingat, dan paham terhadap materi pembelajaran yang diberikan dengan penerapan Guided Inquiry berbantu Memory Match Game. Hal ini sejalan dengan Arsyad (2004) yang menyatakan bahwa multimedia dapat mengakomodasi siswa yang bersifat afektif dengan cara yang lebih individual, tidak lupa, tidak bosan dan menyenangkan.

Pada aspek interpretasi mengalami peningkatan dari prasiklus hingga siklus II. Pada prasiklus menuju siklus I mengalami peningkatan persentase rata-rata aspek menginterpretasi sebesar $9,52 \%$, dari siklus I menuju siklus II mengalami peningkatan 10,71\%. Dari prasiklus ke siklus I masih memiliki nilai yang kecil, hal tersebut terlihat dari hasil diskusi pada masing-masing kelompok disaat diskusi. Pada siklus I siswa juga belum terbiasa dengan model pemebelajaran dan media yang digunakan sehingga siswa masih merasa kebingungan. Terlihat juga bahwa sebagian siswa berkebaratan untuk mengamati awetan dikarenakan bau yang tidak sedap dari awetan. Sedangkan dari siklus I menuju siklus II siswa aktif dalam mengamati awetan, dikarenakan bahan yang diamati masih dalam kondisi segar yang belum diawetkan. Selain itu, masing-masing kelompok mengamati tidak hanya satu kelas dari filum Mollusca, tetapi beberapa kelas, sehingga siswa lebih banyak mendapatkan informasi. Berdasarkan hasil wawancara siswa lebih cenderung fokus pada Memory Match Game mengenai contoh hewan dari Echinodermata daripada mengamati awetan dari hewan yang bau. Untuk mengatasi ini pada siklus II guru membawa hewan segar untuk diamati. Hal tersebut berdampak baik pada informasi yang harus diberikan siswa.

Rata-rata hasil tes dari prasiklus menuju siklus I menunjukkan masing-masing siswa secara sederhana mampu mengkategorisasikan data-data yang mereka butuhkan untuk menjawab pertanyaan dari guru. Beberapa siswa memberikan jawaban hanya berupa tafsiran dari soal yang mereka baca, namun jawaban tersebut sesuai dengan informasi yang dibutuhkan guru mengenai Echinodermata. Tidak hanya menafsirkan tetapi siswa juga mampu menjelaskan jawaban yang mereka sajikan secara jelas mengenai ciri-ciri dari masing-masing kelas pada filum Echinodermata.

Pengalaman yang mereka dapatkan dari game pada Memory Match Game memberikan dampak bertambahnya pengetahuan mereka dalam hal ini pengetahuan tentang nama-nama ilmiah hewan pada filum Echinodermata. Tidak hanya pengetahuan yang didapatkan tetapi juga memberikan dampak yang menyenangkan kepada siswa karena melalui permainan. Hal ini sejalan dengan pernyataan Tapilouw (2008), bahwa pembelajaran menggunakan teknologi multimedia interaktif, dapat meningkatkan pemahaman dan retensi siswa.

Penerapan Guided Inquiry memudahkan siswa untuk menemukan konsep materi, memahami konsep materi, memecahkan masalah. Sejalan dengan hal tersebut Hanafiah dan Suhana (2009) menyatakan bahwa pembelajaran Guided Inquiry membantu peserta didik untuk mengembangkan penguasaan keterampilan dalam proses kognitif, peserta didik lebih mudah dalam memahami materi dan lebih mengendap dalam pikiran siswa dengan proses penyelidikan.

Aspek menganalisis memiliki peningkatan dari prasiklus hingga siklus II. Prasiklus menuju siklus I tidak 
terjadi peningkatan yang besar yaitu hanya sebesar 7,85\% namun dari siklus I menuju siklus II terjadi peningkatan yang cukup signifikan yaitu sebesar $22,86 \%$. Pada siklus I aspek menganalisis masih kurang disebabkan penjelasan guru mengenai materi kurang diperdalam, sehingga siswa merasa belum paham. Siswa pada siklus I cenderung menjelaskan kembali maksud dari pertanyaan pada jawaban tes. Siswa juga menjawab tidak dengan detail. Hal tersebut terlihat pada hasil tes pada siklus I dimana siswa belum menganalisis secara detail mengenai hubungan sistem gerak Echinodermata dengan struktur tubuhnya. Hasil tes berpikir kritis untuk aspek menganalisis pada siklus II menunjukkan peningkatan yang besar. Hal ini disebabkan siswa mulai memahami dan terbiasa dengan model pembelajaran dan media pembelajaran yang memberikan kesempatan siswa untuk lebih bisa menganalisis suatu permasalahan. Siswa mampu mengidentifikasi maksud dari pertanyaan yang diberikan guru mengenai fungsi dari bagian tubuh Mollusca dan karakteristik dari kelas yang yang dapat menghasilkan perhiasan yaitu kelas Bivalvia. Siswa memiliki kemudahan dalam menganalisis suatu informasi karena Guided Inquiry berbantu Memory Match Game memberikan kesempatan siswa untuk melakukan praktikum guna menemukan suatu konsep yang di dalamnya dibutuhkan proses berpikir dan tujuan yang jelas. Selain itu guru telah melakukan perbaikan penanganan mengenai hasil diskusi pada LKS yang diperdalam pada saat penyajian materi.

Hasil wawancara menunjukkan bahwa proses pemahaman siswa sangat terbantu dengan pembelajaran yang menerapkan sistem penemuan dan mengamati secara langsung objek yang dipelajari serta menggunakan media pembelajaran seperti pada Guided Inquiry yang dibantu oleh media game Memory Match Game. Menurut Facione (2011) menganalisis berarti mampu mengidentifikasi maksud dan kesimpulan yang benar antara pernyataan, konsep, deskripsi yang diberikan oleh guru ketika penyajian materi pada pembelajaran tatap muka berlangsung.

Aspek mengevaluasi memiliki peningkatan dari prasiklus hingga siklus II. Prasiklus menuju siklus I tidak terjadi peningkatan yang besar yaitu hanya sebesar $4,28 \%$ namun dari siklus I menuju siklus II terjadi peningkatan yang cukup signifikan yaitu sebesar $16,43 \%$. Siklus I siswa mengalami peningkatan dalam hal mengevaluasi yaitu terlihat pada sajian informasi yang diberikan siswa pada jawaban tes mengenai perbedaan klasifikasi dari kelas pada filum Echinodermata. Tetapi peningkatan sangat kecil, hal ini disebabkan oleh satu kelompok hanya mengamati satu kelas dari filum Echinodermata. Siswa hanya mengetahui informasi kelas-kelas dari filum Echinodermata melalui presentasi. Siklus II siswa mengalami peningkatan yang cukup besar dalam hal mengevaluasi yaitu terlihat pada sajian informasi yang diberikan siswa pada jawaban tes mengenai perbedaan klasifikasi dari kelas pada filum Mollusca. Peningkatan yang cukup besar disebabkan refleksi dari siklus I, pada siklus II setiap kelompok mengamati tiga kelas dari filum Mollusca. Terdapat kesesuaian antara hasil kesimpulan dalam kegiatan diskusi pada LKS dengan jawaban tes membuktikan bahwa siswa mampu mengevaluasi permasalahan yang dihadapi dengan informasi yang diperoleh. Pada siklus II peningkatan aspek mengevaluasi tidak terlepas dari peran guru yang efektif, yaitu guru sukses menciptakan proses pembelajaran yang membawa siswa kearah pemecahan masalah.

Guided Inquiry yang dikombinasikan dengan Memory Match Game dapat mempengaruhi peningkatan dalam hal mengevaluasi. Sejalan dengan hal tersebut Puspita \& Jatmiko (2013) menyatakan bahwa di dalam tahapantahapan pembelajaran Guided Inquiry dapat mengakomodasikan kemampuan berpikir kritis siswa, salah satunya yaitu mengevaluasi. Selain itu dengan Memory Match Game maka siswa dapat mengevaluasi contoh-contoh gambar beserta nama ilmiah dari masingmasing kelas dari Filum tersebut. Sejalan dengan hal tersebut Herlanti, Rustaman \& Setiyawan (2007) menyatakan bahwa tampilan-tampilan multimedia yang mempunyai kekuatan imagery, terbukti mampu menyimpan lebih lama abstraksi-abstraksi konsep di dalam struktur kognitif siswa.

Materi yang disajikan guru pada pembelajaran dengan pengamatan memudahkan siswa untuk melakukan evaluasi terhadap informasi yang mereka dapatkan melalui pengamatan atau praktikum. Siswa dapat membedakan ciri-ciri dari masing-masing kelas pada filum Echinodermata di siklus I dan ciri-ciri dari masing-masing kelas pada filum Mollusca pada siklus II. Hasil wawancara pada aspek mengevaluasi, siswa menyatakan bahwa mereka sudah mampu melakukan evaluasi atas jawabanjawaban yang mereka berikan dengan penerapan Guided Inquiry berbantu Memory Match Game. Siswa menyatakan kegiatan pada proses pembelajaran mendukung penerimaan informasi yang memadai dan mudah dipahami sehingga mereka tidak kesulitan dalam menghubungkan antara hasil pemikiran dengan teori. Hasil tes menunjukkan bahwa siswa mampu menilai pernyataan yang disajikan guru dengan informasi yang mereka dapatkan dari pengamatan dan sumber lain sehingga terlihat suatu hubungan yang logis seperti memberikan penjelasan dengan menambahkan contoh.

Aspek menyimpulkan mengalami peningkatan paling besar diantara aspek berpikir kritis lainnya dari prasiklus hingga siklus II. dari prasiklus menuju siklus I mengalami peningkatan sebesar 20,71\% sedangkan dari siklus I ke siklus II mengalami peningkatan 14,29\%. Hasil tes yang siswa kerjakan pada siklus I sudah mengarah pada indikator menyimpulkan, secara garis besar informasi yang disimpulkan sudah sistematis dan jelas. Ada beberapa siswa yang kurang menyimpulkan dengan sistematis dan jelas. Hal ini disebabkan kesimpulan yang diberikan berdasarkan pengamatan. Pada siklus II peningkatan menyimpulkan tidak terlepas dari perbaikan pada siklus I yaitu guru menyajikan informasi kepada siswa secara lebih sistematis dan saling berkaitan antara diskusi dengan konfirmasi dari guru. Hasil tes pada siklus II terlihat bahwa siswa mampu menyajikan kesimpulan informasi yang mereka dapatkan mengenai ciri-ciri dari hewan yang mereka amati secara lebih jelas dan sistematis. Hasil 
wawancara dengan siswa diperoleh informasi yang lebih luas baik dalam hal menyimpulkan merasa terbantu melalui penerapan Guided Inquiry berbantu Memory Match Game, dimana menyimpulkan sebenarnya membutuhkan alur logika yang jelas. Menyimpulkan fakta atas informasi yang didapatkan merupakan suatu proses berpikir kritis. Rangkaian logika harus disusun secara jelas dan sistematis sehingga menghasilkan pernyataan yang logis.

Aspek penjelasan juga mengalami peningkatkan dari prasiklus hingga siklus II. Hasil tes siswa pada siklus I secara garis besar hanya memberikan penjelasan dari informasi yang diperoleh, namun pada siklus II siswa menunjukkan hal yang berbeda pada jawaban tes berpikir kritis untuk aspek menjelaskan. Hal tersebut terlihat pada kualitas jawaban tes siklus II yaitu siswa memberikan penjelasan yang meyakinkan untuk membuktikan suatu kebenaran dari informasi mengenai reproduksi pada Mollusca khususnya Gastropoda dengan menambahkan alasan yang kuat. Hasil wawancara diperoleh informasi bahwa siswa sudah mampu memberikan penjelasan yang baik dan benar mengenai informasi yang ditanyakan dengan penerapan Guided Inquiry berbantu Memory Match Game.

Kemampuan berpikir kritis siswa mengenai aspek penjelasan berkembang melalui interaksi siswa dalam kegiatan diskusi kelompok dan kelas yang terjadi selama siklus pertama sampai siklus kedua. Penjelasan suatu informasi secara lebih mendalam dapat dilakukan dengan pengumpulan informasi yang lebih luas. Guided Inquiry berbantu Memory Match Game mampu mengembangkan daya jelajah siswa dalam memperoleh informasi tanpa harus mengawang-awang materi.

Aspek kemampuan berpikir kritis pengaturan diri juga meningkat pada setiap siklus. Dari prasiklus menuju siklus I mengalami peningkatan yang sangat kecil yaitu sebesar 1,42\% sedangkan dari siklus I menuju siklus II mempunyai peningkatan persentase yang cukup tinggi yaitu sebesar $18,85 \%$. Hasil tes pada siklus I menunjukkan bahwa siswa kurang mampu menggunakan elemen-elemen yang digunakan dalam proses berpikir seperti hasil diskusi menggunakan LKS di kelas. Pengaturan diri berkaitan dengan kemampuan siswa dalam menganalisis dan mengevaluasi kemampuan diri dalam mengambil kesimpulan dengan bentuk konfirmasi dari hasil diskusi kelompok.

Guru melakukan beberapa perbaikan dalam membimbing siswa melakukan refleksi terhadap informasi yang diperoleh siswa melalui diskusi LKS. LKS yang diberikan pada siswa pada siklus I dan siklus II memberikan kesempatan bagi semua siswa untuk memecahkan setiap masalah yang tersaji dalam LKS secara berkelompok. Jawaban pada siklus I dan siklus II sebagian besar siswa menunjukkan bahwa kegiatan siswa sebagai alternatif jawaban dengan disertai penjelasan untuk masing-masing individu memiliki pengaturan penjelasan yang berbeda-beda dan beberapa hampir serupa dalam menyajikan informasi dan contoh berdasarkan bukti. Hal tersebut dapat dicontohkan seperti jawaban mengenai bentuk cangkang bivalvia yang disertai gambar. Hasil wawancara pada aspek pengaturan diri, siswa merasa terbantu dalam mengoreksi kembali jawaban yang diberikan dengan penerapan Guided Inquiry berbantu Memory Match Game. Siswa mengatakan bahwa penyajian materi mudah dipahami. Kesimpulan yang mudah dihasilkan pada proses pembelajaran sangat membantu dalam mengerjakan tes.

Berdasarkan penelitian tindakan kelas yang telah dilakukan, penerapan model pembelajaran Guided Inquiry berbantu Memory Match Game meningkatkan retensi dan kemampuan berpikir kritis siswa karena model pembelajaran inkuiri merupakan salah satu suatu pembelajaran yang mendukung guru dan siswa dan digunakan untuk berpikir karena didalam proses inkuiri terdapat planning, retrieving, processing, creating, sharing and evaluating yang semuanya dapat dijadikan sebagai intruksi, sebagai pengukur, sebagai bahasa antara siswa dan guru, membimbing siswa (Alberta, 2004). Memory match game dapat meningkatkan retensi siswa karena melalui game siswa akan merasa senang dengan game tersebut, kemudian siswa akan berusaha mengingat dan menghafal apa yang ia peroleh didalam game tersebut. Game akan membuat siswa tertarik karena berbasis visual. Dengan adanya memory match game ini siswa dapat belajar dengan bantuan permainan yang menarik. Pada dasarnya memory match game ini berbasis ingatan.

Sadia (2008) mengemukakan bahwa berpikir kritis tidak dapat diajarkan melalui metode ceramah, karena berpikir kritis merupakan proses aktif. Berpikir kritis dapat diajarkan melalui kegiatan laboratorium, penemuan, pekerjaan rumah yang mengembangkan kemampuan berpikir kritis, dan ujian yang dirancang untuk membangun kemampuan berpikir kritis. Berpikir kritis dapat diajarkan melalui data empiris dan permasalahan yang diberikan (Masek, 2011). Retensi siswa dengan menggunakan multimedia lebih tinggi dari pada siswa yang tidak menggunakan multimedia, ini menandakan tampilantampilan multimedia yang mempunyai kekuatan imagery, terbukti mampu menyimpan lebih lama abstraksi-abstraksi konsep di dalam struktur kognitif siswa (Herlanti,Rustaman, \& Setiawan (2007).

Hasil wawancara kepada siswa menunjukkan bahwa model pembelajaran Guided Inquiry berbantu Memory Match Game meningkatkan retensi dan kemampuan berpikir kritis siswa. Siswa lebih senang dengan menggunakan model pembelajaran seperti ini dibandingkan dengan pembelajaran dengan metode ceramah seperti pada pembelajaran pra-siklus.

\section{KESIMPULAN}

Kesimpulan penelitian ini adalah penerapan Guided Inquiry berbantu Memory Match Game dapat meningkatkan retensi dan kemampuan berpikir kritis siswa kelas X SMA.

\section{DAFTAR PUSTAKA}

Anderson. L.W \& Krathwohl, D. (2010). A Taxonomy for Learning Teaching and Assesing. A Revision of 
Bloom's Taxonomy of Educational Objectives. New York: Addison Wesley Longman, Inc.

Alberta. (2007). Focus On Inquiry. Canada: Alberta Learning.

Bell, R. L., Smetana, L., \& Binns, I. (2005, October). Simplifying Inquiry Assosiation. National Science Teacher Association, 30-33.

Budiartini, N. L., Arcana, I. N., \& Margunayasa, G. I. (2013). Pengaruh Model Pembelajaran Inquiri Terbimbing Terhadap Kemampuan Berpikir Kritis IPA Siswa Kelas V Di SD 7 Datah. Jurusan PGSD, FIP Universitas Pendidikan Ganesha .

Caffee, J. (2010). Thinking Citically: Tenth Edition. Boston, USA: Wadsworth.

Chin, C. (2013). Implementing Problem Based Learning in Biology. Nanyang Technological University, Singapore.

Elder, L., \& Paul, R. (2007). Critical Thinking: Competency Standards Essential for the Cultivation of Intellectual Skills, Part 1. Journal of Developmental Education , 38-39.

Facione, P. A. (2011). Critical Thinking: What It Is and Why It Counts. Measured reason and the California Academic Press .

Hanafiah \& Suhana. 2009. Konsep Strategi Pembelajaran. Bandung: Revita Aditama.

Herlanti, Y., Rustaman, N. Y., \& Setiawan, W. (2007, April). Kontribusi Wacana Multimedia Terhadap Pemahaman dan Retensi Siswa. Jurnal Pendidikan IPA: Metamorfosa , 29-38.

Masek, A. (2011). The Effect of Problem Based Learning on Critical Thinking Ability : A Theorical and Empirical Review. International Review of Social Sciences and Humanities , 2 (1), 215-221.

Pradana, Radyan. (2011). Pengembangan Media Pembelajaran Biologi Uji Makanan Menggunakan Adobe Flash Professional CS5. Universitas Negeri Yogyakarta.

Puspita, A. T., \& Jatmiko, B. (2013). Implementasi Model Pembelajaran Inkuiri Terbimbing (Guided Inquiry) terhadap Ketrampilan Berpikir Kritis Siswa pada Pembelajaran Fisika Materi Fluida. Jurnal Inovasi Pendidikan Fisika , 2 (3), 121-125.

Sadia, I. W. (2008). Model Pembelajaran yang Efektif Untuk Meningkatkan Ketrampilan Berpikir Kritis (Suatu Persepsi Guru). Jurnal Pendidikan dan Pengajaran Undiksha, 2 (2), 19-237.

Sumaryati, E., \& Sumarmo, U. (2013). Pendekatan Induktif-Deduktif disertai Strategi Think-Pair-SquareShare untuk Meningkatkan Kemampuan Pemahaman dan Berpikir Kritis disertai Disposisi Matematis Siswa SMA. Jurnal Ilmiah Program Studi Matematika STKIP Siliwangi Bandung, 2 (1).

Sutama, I. N., Arnyana, I. B., \& Swasta, I. B. (2014). Pengaruh Model Pembelajaran Inkuiri Terhadap Kemampuan Berpikir Kritis Dan Kinerja Ilmiah Pada Pembelajaran Biologi Kelas XI IPA SMA Negeri 2 Amlapura. e-Journal Program Pascasarjana Universitas Pendidikan Ganesha , 4.

Tapilouw, F., \& Setiawan, W. (2008). Meningkatkan Pemahaman dan Retensi Siswa Melalui Pembelajaran Berbasis Teknologi Multimedia Interaktif. Jurnal
Pendidikan Teknologi Informasi dan Komunikasi , 1 (2), 19-25.

Trianto. (2010). Model Pembelajaran Terpadu. Jakarta: Bumi Aksara.

\section{Daftar Pustaka Gambar Memory Match Game}

http://www.waterframe.com/ansichtgalerie_niederes-153fur54927.htm

http://wondercreation.blogspot.com/2010/12/punggolshore-surprises.html

http://diffractionmarine.net/piwigo/picture.php?/257

http://www.pbase.com/botb/image/111555511

http://www.jaxshells.org/0628aa.htm

http://www.enasco.com/product/LS03607M

http://www.horta.uac.pt/projectos/Saber/200310/ADSM.ht $\mathrm{m}$

http://www.gulfspecimen.org/specimen/echinodermata/se a-cucumbers/

http://www. url.edu

http://blognyaabuabdillah.blogspot.com/

http://blogpembelajaranbiologi.blogspot.com/2013/04/crin oidea.html

http://fr.wikipedia.org/wiki/Antedon

http://waste.ideal.es/especies60.html

http://en.wikipedia.org/wiki/Achatina

http://ipp.boku.ac.at/private/wf/Helix_pomatia.html

http://commons.wikimedia.org/wiki/File:Limax_maximus 3.jpg

http://www.topseashell.com/15601-pinctada-sp-.html

http://darkerview.com/darkview/index.php?/archives/861 Postcard-from-the-Reef-Oyster.html

http://en.wikipedia.org/wiki/File:Loligo vulgaris.jpg

http://www.flmnh.ufl.edu/reefs/guamimg/cephalopoda/Pa ges/Image15.html

http://www.waza.org/en/zoo/visit-the-zoo/snailscuttlefish-octopus-and-relatives-mollusca1254385523/nautilus-sp.

http://www.naturamediterraneo.com/Forum/pop printer f riendly.asp?TOPIC $\mathrm{ID}=7001$ 